\title{
TINGKAT PENGUASAAN SISWA KELAS X SMA ISLAM PARLAUNGAN SIDOARJO DALAM MENYELESAIKAN SOAL CERITA BERBASIS GAYA BELAJAR
}

\author{
Ardianik $^{1}$, Boedi Martono ${ }^{2}$, Windi Setiawan ${ }^{3}$ \\ ${ }^{1,2,3}$ FKIP Universitas Dr. Soetomo Surabaya \\ ardianik@unitomo.ac.id
}

\begin{abstract}
Abstrak
Penelitian ini bertujuan untuk mendeskripsikan sejauh mana tingkat penguasaan siswa kelas X SMA Islam Parlaungan berbasis gaya belajar visual, auditori, dan kinestetik dalam menyelesaikan soal cerita sistem persamaan linear tiga variabel. Penelitian ini termasuk jenis penelitian deskriptif dengan pendekatan kualitatif. Subjek dalam penelitian ini adalah siswa kelas X SMA Islam Parlaungan Sidoarjo yang berjumlah 49 siswa, yang berbasis gaya belajar visual ada 21 siswa, gaya belajar auditori ada 16 siswa, dan gaya belajar kinestetik ada 12 siswa.Metode pengumpulan data yang digunakan dengan memberikan angket gaya belajar dan metode tes. Metode analisis data yang digunakan yaitu analisis data hasil tes dengan mengklasifikasikan tingkat penguasaan siswa berdasarkan nilai kriteria kelulusan minimal (KKM) mata pelajaran matematika yaitu 75 dan mengklasifikasikan tingkat penguasaan siswa berdasarkan nilai mean dan standar deviasi. Hasil penelitian menyimpulkan bahwa: (1) Tingkat penguasaan materi berdasarkan nilai KKM, menunjukkan bahwa tingkat penguasaan siswa visual pada materi soal cerita sistem persamaan linear tiga variabel ada $8,2 \%$ yang menguasai dan ada $34,7 \%$ yang tidak menguasai. Tingkat penguasaan materi siswa auditori ada $6,1 \%$ yang menguasai dan ada $26,5 \%$ yang tidak menguasai. Tingkat penguasaan materi siswa kinestetik tidak ada $0 \%$ yang menguasai dan ada $24.5 \%$ yang tidak menguasai; (2) Tingkat penguasaan materi berdasarkan nilai mean dan standart deviasi, menunjukkan bahwa tingkat penguasaan siswa visual pada materi soal cerita sistem persamaan linear tiga variabel tergolong klasifikasi tinggi ada 8,2\%, tergolong klasifikasi sedang ada 28,6\%, dan tergolong klasifikasi rendah ada 6,1\%. Tingkat penguasaan materi siswa auditori yang tergolong klasifikasi tinggi ada 6,1\%, tergolong klasifikasi sedang ada 26,5\%, dan tidak ada $0 \%$ yang tergolong klasifikasi rendah. Tingkat penguasaan materi siswa kinestetik tergolong klasifikasi tinggi tidak ada (0\%), tergolong klasifikasi sedang ada $14,3 \%$, dan yang tergolong klasifikasi rendah ada $10,2 \%$.
\end{abstract}

Kata Kunci: Tingkat Penguasaan, Sistem Persamaan Linear Tiga Variabel, Gaya Belajar

\section{PENDAHULUAN}

Matematika merupakan salah satu mata pelajaran yang diajarkan pada setiap jenjang pendidikan. Matematika dianggap dapat membentuk peserta didik yang mampu menghadapi perkembangan dunia, terutama perkembangan ilmu pengetahuan, teknologi dan komunikasi. Penguasaan matematika dianggap penting untuk memenuhi kebutuhan pengembangan ilmu matematika itu sendiri, ilmu lain, maupun untuk kehidupan sehari-hari (Julita, 2018:144).

Matematika adalah konsep ilmu yang mempelajari tentang logika mengenai bentuk, susunan, besaran, dan konsep-konsep yang berhubungan satu dengan yang lainnya dalam memberikan strategi untuk mengatur, menganalisis dan mensintesis data atau semua yang ditemui dalam masalah sehari-hari. Pelajaran metematika berkenaan dengan ide-ide, konsep-konsep abstrak yang tersusun secara hirarki dan penalaran deduktif. Oleh karena itu, pembelajaran matematika haruslah bertahap serta berkelanjutan agar dalam proses pembelajarannya terjadi proses berpikir. Oleh karena itu dalam menyusun teknik dan metode mengajar, guru haruslah memperhatikan perbedaan gaya belajar siswa agar proses pembelajaran dapat berjalan dengan lancar (Syukur, 2016:155).

Banyak ahli yang mengartikan matematika baik secara umum maupun secara khusus. Hudoyo (1998) menyatakan bahwa: "Matematika merupakan ide-ide abstrak yang diberikan simbol-simbol itu tersusun secara hirarkis dan penalarannya deduktif, sehingga belajar matematika itu merupakan kegiatan mental yang tinggi”. Sedangkan James dalam kamus matematikanya menyatakan bahwa: "Matematika adalah ilmu tentang logika mengenai bentuk, susunan, besaran dan konsep-konsep yang saling 
berhubungan, yang terbagi ke dalam tiga bidang yaitu aljabar, analisis, dan geometri" (Hasratuddin, 2014:30).

Prestasi belajar seseorang dipengaruhi oleh berbagai faktor yang salah satunya adalah penguasaan materi, yaitu kemampuan yang dicapai siswa pada sejumlah mata pelajaran setelah melakukan pembelajaran untuk mancapai tujuan pendidikan. Masalah utama yang sering dihadapi pada pendidikan di sekolah adalah rendahnya daya serap siswa terhadap materi pelajaran terutama matematika. Matematika merupakan suatu ilmu yang mempelajari tentang konsep-konsep yang saling berkaitan yang satu dengan yang lainnya. Berawal dari konsep yang sederhana hingga berlanjut ke konsep yang lebih kompleks. Ketika akan mempelajari bab berikutnya maka bab sebelumnya harus dikuasai, karena syarat untuk bisa berlanjut mempelajari ke bab berikutnya yaitu harus menguasai bab sebelumnya. Mempelajari matematika harus bertahap dan terstruktur dimulai dari hal yang sederhana hingga berlanjut ke hal yang kompleks. Oleh karena itu penguasaan materi sangat diperlukan (Evie, 2016:2).

Masalah dalam matematika berbeda dengan soal matematika. Masalah matematika sudah pasti merupakan soal matematika, tetapi soal matematika belum tentu merupakan masalah matematika. Suatu soal matematika dapat dikatakan masalah matematika jika soal tersebut tidak dapat diselesaikan secara langsung dengan rumusrumus yang telah tersedia. Masalah matematika biasanya dinyatakan dalam bentuk soal cerita, baik tertulis atau verbal. Masalah matematika dalam bentuk soal cerita lebih sulit dipecahkan oleh siswa dibandingkan dengan soal-soal yang hanya melibatkan bilangan-bilangan atau soal yang hanya terkait dengan perhitungan angka-angka. Dalam menyelesaikan soal cerita siswa terlebih dulu dituntut untuk mengetahui apa yang diketahui, apa yang ditanya dan mengubah ke dalam model matematika sebelum menggunakan strategi penyelesaian yang tepat (Siti, 2016:2).

Menurut Polya dalam penyelesaian suatu masalah terdapat empat langkah yang harus dilakukan: (1) Memahami masalah (Understanding the problem) yaitu mampu mengungkapkan apa yang diketahui dan apa yang ditanyakan dari soal, dan mampu memahami apakah keterangan yang diberikan cukup untuk mencari apa yang ditanyakan; (2) Menyusun rencana penyelesaian (Devising the plan) yaitu mampu menyusun model matematika, meliputi kemampuan merumuskan masalah situasi seharihari dalam matematika, serta menentukan alternatif pemecahan masalah; (3) Melaksanakan rencana penyelesaian (Carrying out the plan) yaitu mampu memilih dan mengembangkan strategi pemecahan masalah, mampu memunculkan alternatif cara pemecahan masalah serta pengetahuan sebelumnya yang dapat digunakan untuk mendukung kegiatan pemecahan masalah; (4) Memeriksa kembali (Looking a back) yaitu mampu mengidentifikasi kesalahan perhitungan, penggunaan rumus, memeriksa kecocokan antara yang telah ditemukan dengan apa yang ditanyakan, dan dapat membuat kesimpulan yang tepat (Rahmawati,2018:24).

Gaya belajar merupakan cara termudah yang dimiliki oleh individu dalam menyerap, mengatur, dan mengolah informasi yang diterima. Gaya belajar yang sesuai adalah kunci keberhasilan siswa dalam belajar. Dengan menyadari hal ini, siswa mampu menyerap dan mengolah informasi dan menjadikan belajar lebih mudah dengan gaya belajar siswa sendiri. Penggunaan gaya belajar yang dibatasi hanya dalam satu bentuk, terutama yang bersifat verbal atau dengan jalur auditorial, tentunya dapat menyebabkan adanya ketimpangan dalam menyerap informasi. Oleh karena itu, dalam kegiatan belajar, siswa perlu dibantu dan diarahkan untuk mengenali gaya belajar yang sesuai dengan dirinya sehingga tujuan pembelajaran dapat dicapai secara efektif (Arylien, 2014:169).

Hasil penelitian Hartati (2013: 233) menyimpulkan bahwa: terdapat perbedaan hasil belajar matematika antara siswa yang memiliki gaya belajar visual, auditorial, dan kinestetik. Di dukung hasil penelitian dari Nyoto dkk. (2015:561) mengatakan bahwa Siswa dengan gaya belajar visual mempunyai prestasi belajar matematika yang lebih baik dengan siswa yang mempunyai gaya belajar auditorial. Sedangkan siswa dengan gaya belajar auditorial mempunyai prestasi belajar matematika yang lebih baik dengan siswa yang mempunyai gaya belajar kinestetik.

Tidak semua siswa memiliki gaya belajar yang sama, dimana setiap siswa memiliki gaya belajar yang alami dan nyaman bagi mereka masing-masing. Sebagian siswa lebih suka bila guru mereka mengajar dengan menuliskan semuanya di papan tulis, sehingga mereka dapat membacanya dan memahaminya. Tetapi sebagian siswa lain lebih suka guru menyampaikan materi secara lisan sehingga mereka dapat mendengarkan dan memahami. Ada juga siswa yang lebih suka membentuk kelompok kecil dan mendiskusikan materi pelajaran. Selain itu ada juga siswa yang lebih suka dengan pembelajaran yang menggunakan alat peraga (Syukur, 2016:155). Menurut Sutrisno (2013:662) siswa yang belajar dengan gaya belajar mereka yang dominan saat mengerjakan tes, akan mencapai nilai yang jauh lebih tinggi dibandingkan bila mereka belajar dengan cara yang tidak sejalan dengan gaya belajar mereka.

Berawal dari tim peneliti sebagai dosen pembimbing program pengalaman lapangan (PPL), tidak sengaja ada masukan dari guru matematika kelas X SMA Islam Parlaungan yang mengatakan bahwa pelajaran matematika sangat sulit bagi siswa, sehingga siswa tidak bersungguhsungguh dalam mengikuti kegiatan pembelajaran. Siswa juga memiliki kekurangan dalam pemahaman konsep 
matematika di tingkat SMP, sehingga siswa sulit untuk memahami pembelajaran di tingkat yang lebih tinggi, terutama materi matematika yang abstrak, salah satunya yaitu sistem persamaan linear tiga variabel. Ketika diberikan beberapa soal cerita yang berhubungan dengan materi sistem persamaan linear dua variabel yang telah dipelajari di tingkat SMP, para siswa tersebut masih kesulitan menjawab soal cerita tersebut. Yang artinya apabila materi sistem persamaan linear dua variabel belum terkuasai dengan baik maka siswa akan kesulitan menyelesaikan bentuk soal cerita yang berhubungan dengan materi sistem persamaan linear tiga variabel, yang akhirnya hasil belajar yang didapat kurang memuaskan. Dalam menyelesaikan sistem persamaan linear tiga variabel yang berbentuk soal cerita diperlukan ketelitian yang tinggi dan pemahaman konsep yang benar agar diperoleh hasil yang benar.

Terkait dengan temuan di atas, dapat disimpulkan bahwa masih sangat diperlukan upaya menggali potensi siswa yang lebih maksimal untuk meningkatkan pemahaman materi sistem persamaan linier tiga variabel dengan tujuan untuk memperoleh hasil belajar yang lebih baik. Salah satu faktor yang berpengaruh terhadap hasil belajar adalah gaya belajar. Dengan demikian permasalahan dari penelitian ini adalah bagaimanakah tingkat penguasaan siswa kelas X SMA Islam Parlaungan Sidoarjo berbasis gaya belajar visual, auditori, dan kinestetik dalam menyelesaikan soal cerita sistem persamaan linear tiga variabel.

\section{METODE}

Penelitian ini bertujuan untuk mendeskripsikan sejauh mana tingkat penguasaan siswa kelas X SMA Islam Parlaungan berbasis gaya belajar visual, auditori, dan kinestetik dalam menyelesaikan soal cerita sistem persamaan linear tiga variabel. Peneliti tidak melakukan manipulasi atau memberikan perlakuan khusus terhadap subjek penelitian, tetapi menggambarkan semua yang terjadi dengan apa adanya dan mendeskripsikan tingkat penguasaan siswa dalam bentuk kata-kata dan bahasa sehingga penelitian ini termasuk jenis penelitian deskriptif dengan pendekatan kualitatif (Moleong,2015:8; Emzir, 2014:11)

Subjek dalam penelitian ini adalah siswa kelas X SMA Islam Parlaungan Sidoarjo yang berjulah 49 siswa, yang berbasis gaya belajar visual ada 21 siswa, gaya belajar auditori ada 16 siswa, dan gaya belajar kinestetik ada 12 siswa. Penentuan subyek ini atas pertimbangan hasil angket gaya belajar yang cenderung ekstrim pada masing-masing gaya belajar visual, auditori, dan kinestetik. Pada penelitian ini subyek penelitian tidak dipilih secara acak, tetapi menggunakan pemilihan sampel bertujuan (purposive sampling) karena dalam penelitian ini subyek penelitian dikelompokkan berdasarkan masing-masing gaya belajar untuk mengetahui tingkat penguasaan siswa dalam menyelesaikan soal.

Metode pengumpulan data digunakan dengan memberikan angket gaya belajar dan metode tes. Kuesioner atau angket gaya belajar merupakan sejumlah pertanyaan tertulis yang digunakan untuk memperoleh informasi dari responden tentang pribadinya kaitannya untuk memperoleh data sejauh mana gaya belajar siswa secara umum. Tes diberikan untuk mengetahui sejauh mana tingkat penguasaan siswa pada materi soal cerita sistem persamaan linear tiga variabel. Jenis tes yang digunakan peneliti adalah tes prestasi. Tes prestasi belajar digunakan untuk mengukur penguasaan dan kemampuan para peserta didik selama waktu tertentu menerima proses belajar mengajar dari guru (Sukardi, 2012:139).

Metode analisis data yang digunakan yaitu analisis data hasil tes tulis. Langkah-langkah analisis data hasil tes adalah sebagai berikut; 1) pemberian skor hasil jawaban siswa pada setiap soal tes berdasarkan kunci jawaban dan pedoman penskoran; 2) mengklasifikasikan tingkat penguasaan siswa berdasarkan nilai kriteria kelulusan minimal (KKM) mata pelajaran matematika di SMA Islam Parlaungan Sidoarjo yaitu 75, jika nilai siswa lebih besar atau sama dengan nilai KKM maka siswa tersebut dikatakan menguasai, dan jika nilai matematika siswa kurang dari nilai KKM maka siswa tersebut dikatakan tidak menguasai;4) mengklasifikasikan tingkat penguasaan siswa berdasarkan nilai mean dan standar deviasi yang diperoleh dari hasil tes, yaitu yang termasuk klasifikasi tinggi adalah ketika nilai tes siswa lebih dari mean ditambah standar deviasi, sedangkan yang termasuk klasifikasi rendah ketika nilai tes siswa kurang dari mean dikurang standar deviasi, dan yang termasuk klasifikasi sedang adalah ketika nilai tes siswa antara klasifikasi tinggi dan klasifikasi rendah (Sudijono, 2012: 43). Secara lebih jelas bisa dilihat pada tabel 1.1 di bawah ini; 5) membuat kesimpulan terhadap hasil tes yang telah dianalisis.

Tabel 1. Kriteria Pengelompokan Siswa

\begin{tabular}{cc}
\hline Klasifikasi & Kriteria Pengelompokan \\
\hline Tinggi & $\mathrm{X}>\mathrm{M}+\mathrm{SD}$ \\
Sedang & $\mathrm{M}-\mathrm{SD} \leq \mathrm{X} \leq \mathrm{M}+\mathrm{SD}$ \\
Rendah & $\mathrm{X}<\mathrm{M}-\mathrm{SD}$
\end{tabular}

Berdasarkan tabel 1.1 maka peneliti mengklasifikasikan tingkat penguasaan siswa sebagai berikut: jika hasil tes siswa masuk klasifikasi tinggi, maka siswa tersebut tingkat penguasaannya tergolong sangat menguasai, jika hasil tes siswa masuk klasifikasi sedang, 
maka siswa tersebut tingkat penguasaannya tergolong menguasai, dan jika hasil tes siswa masuk klasifikasi rendah, maka siswa tersebut tingkat penguasaannya tergolong kurang menguasai.

\section{HASIL DAN PEMBAHASAN}

Analisis Data Hasil Tes Berdasarkan Nilai KKM Di Tinjau Dari Gaya Belajar

Dari analisis data hasil tes soal cerita sistem persamaan linear tiga variabel dari 49 siswa, dapat di deskripsikan tingkat penguasaan siswa berdasarkan nilai KKM sebagai berikut: banyaknya siswa yang mendapat nilai diatas atau sama dengan nilai KKM (75) sebanyak tujuh siswa $(14,3 \%)$, sehingga tingkat penguasaannya dikatakan menguasai materi sistem persamaan linear tiga variabel yang terdiri dari empat siswa $(8,2 \%)$ dengan gaya belajar visual, tiga siswa $(6,1 \%)$ dengan gaya belajar auditori, dan tidak ada siswa dengan gaya belajar kinestetik yang menguasai materi. Sedangkan hasil tes yang dibawah nilai KKM sebanyak 42 siswa $(85,7 \%)$, tingkat penguasaannya dikatakan tidak menguasai materi yang terdiri dari 17 siswa $(34,7 \%)$ dengan gaya belajar visual, 13 siswa $(26,5 \%)$ dengan gaya belajar auditori, dan 12 siswa dengan gaya belajar kinestetik $(24,5 \%)$. Jadi dapat disimpulkan bahwa tingkat penguasaan siswa dalam memecahkan soal cerita sistem persamaan linear tiga variabel yang dikatakan menguasai sebanyak $14,3 \%$ dan yang tidak menguasai materi sebanyak $85,7 \%$, hal ini terbukti bahwa siswa kelas $\mathrm{X}$ belum menguasai materi soal cerita yang sifatnya masih abstrak khususnya soal cerita sistem persamaan linear tiga variabel.

\section{Analisis Data Hasil Tes Berdasarkan Kriteria Pengelompokan Nilai Rata - Rata dan Standart Deviasi Ditinjau Dari Gaya Belajar}

Dari analisis data hasil tes soal cerita sistem persamaan linear tiga variabel dari 49 siswa, diperoleh nilai rata-rata yaitu 44 dan nilai standar deviasi 16,6 yang dapat dilihat pada Tabel 2 klasifikasi dan kriteria pengelompokan.

Tabel 2. Klasifikasi Dan Kriteria Pengelompokan

\begin{tabular}{cll}
\hline Klasifikasi & \multicolumn{2}{c}{ Kriteria Pengelompokan } \\
\hline Tinggi & $x>M+S D$ & $x>60,6$ \\
\hline Sedang & $M-S D \leq x$ & $27,4 \leq x$ \\
& $\leq M+S D$ & $\leq 60,6$ \\
\hline Rendah & $x<M-S D$ & $x<27,4$ \\
\hline
\end{tabular}

Dari hasil analisis data hasil tes berdasarkan klasifikasi pengelompokan siswa yang dapat dilihat pada Tabel 2 terinci sebagai berikut: dari 49 siswa yang termasuk tingkat penguasaan materi sistem persamaan linear tiga variabel tergolong klasifikasi tinggi ada tujuh siswa $(14,3 \%)$ yang terdiri dari empat siswa $(8,2 \%)$ dengan gaya belajar visual, tiga siswa $(6,1 \%)$ dengan gaya belajar auditori, dan tidak ada siswa $(0 \%)$ dengan gaya belajar kinestetik yang tergolong tingkat penguasaan tinggi. Banyaknya siswa yang termasuk tingkat penguasaan materi sistem persamaan linear tiga variabel tergolong klasifikasi sedang ada 34 siswa $(69,4 \%)$ yang terdiri dari 14 siswa $(28,6 \%)$ dengan gaya belajar visual, 13 siswa $(26,5 \%)$ dengan gaya belajar auditori, dan tujuh siswa (14,3\%) dengan gaya belajar kinestetik yang tergolong tingkat penguasaan sedang. Banyaknya siswa yang termasuk tingkat penguasaan materi sistem persamaan linear tiga variabel tergolong klasifikasi rendah ada delapan siswa (16,3\%) yang terdiri dari tiga siswa $(6,1 \%)$ dengan gaya belajar visual, tidak ada siswa $(0 \%)$ dengan gaya belajar auditori, dan lima siswa $(10,2 \%)$ dengan gaya belajar kinestetik.

Dari hasil penelitian yang sudah diuraikan diatas, maka tingkat penguasaan siswa pada materi sistem persamaan linear tiga variabel baik berdasarkan nilai KKM maupun nilai mean dan standar deviasi akan dibahas sebagai berikut.

\section{Tingkat Penguasaan Siswa Berdasarkan Nilai KKM}

Tingkat penguasaan siswa visual pada materi soal cerita sistem persamaan linear tiga variabel ada empat siswa $(8,2 \%)$ yang menguasai dan ada 17 siswa $(34,7 \%)$ yang tidak menguasai. Tingkat penguasaan siswa auditori pada materi soal cerita sistem persamaan linear tiga variabel ada tiga siswa $(6,1 \%)$ yang menguasai dan ada 13 siswa $(26,5 \%)$ yang tidak menguasai. Tingkat penguasaan siswa kinestetik pada materi soal cerita sistem persamaan linear tiga variabel tidak ada siswa $(0 \%)$ yang menguasai dan ada 12 siswa (24.5\%) yang tidak menguasai. Lebih jelasnya dapat dilihat pada Tabel 3 di bawah ini.

Tabel 3. Hasil Rekapitulasi Tingkat Penguasaan Berbasis Gaya Belajar

\begin{tabular}{|c|c|c|c|c|c|c|c|c|}
\hline \multirow{4}{*}{$\begin{array}{l}\text { Nil } \\
\text { ai } \\
\mathrm{K} \\
\mathrm{K}\end{array}$} & \multicolumn{6}{|c|}{ Gaya Belajar } & \multirow{5}{*}{$\begin{array}{c}\text { Tot } \\
\text { al }\end{array}$} & \multirow{5}{*}{$\begin{array}{l}\text { Tingka } \\
\mathrm{t} \\
\text { Pengu } \\
\text { asaan }\end{array}$} \\
\hline & \multicolumn{2}{|c|}{ Visual } & \multicolumn{2}{|c|}{ Auditori } & \multicolumn{2}{|c|}{$\begin{array}{c}\text { Kinestet } \\
\text { ik }\end{array}$} & & \\
\hline & $\sum$ & $\%$ & $\sum$ & $\%$ & $\sum$ & $\%$ & & \\
\hline & Sis & & Sis & & Sis & & & \\
\hline & wa & & wa & & wa & & & \\
\hline$\underset{75}{\geq}$ & 4 & $\begin{array}{l}8, \\
2\end{array}$ & 3 & $\begin{array}{c}6, \\
1\end{array}$ & 0 & 0 & $\begin{array}{l}14, \\
3 \%\end{array}$ & $\begin{array}{l}\text { Mengu } \\
\text { asai }\end{array}$ \\
\hline$<$ & 17 & 34 & 13 & 26 & 12 & 24 & 85, & Tidak \\
\hline 75 & &, 7 & & ,5 & &, 5 & $7 \%$ & $\begin{array}{l}\text { Mengu } \\
\text { asai }\end{array}$ \\
\hline
\end{tabular}




\section{Tingkat Penguasaan Siswa Berdasarkan Nilai Rata-Rata Dan Standar Deviasi}

Tingkat penguasaan siswa visual pada materi sistem persamaan linear tiga variabel tergolong klasifikasi tinggi ada empat siswa $(8,2 \%)$, tergolong klasifikasi sedang ada 14 siswa $(28,6 \%)$, dan tergolong klasifikasi rendah ada tiga siswa $(6,1 \%)$. Tingkat penguasaan siswa auditori pada materi sistem persamaan linear tiga variabel tergolong klasifikasi tinggi ada tiga siswa $(6,1 \%)$, tergolong klasifikasi sedang ada 13 siswa (26,5\%), dan tidak ada siswa $(0 \%)$ yang tergolong klasifikasi rendah. Tingkat penguasaan siswa kinestetik pada materi sistem persamaan linear tiga variabel tergolong klasifikasi tinggi tidak ada (0\%), tergolong klasifikasi sedang ada tujuh siswa $(14,3 \%)$, dan yang tergolong klasifikasi rendah ada 5 siswa $(10,2 \%)$. Lebih jelasnya secara rinci dapat dilihat pada Tabel 4 sebagai berikut.

Tabel 4. Tingkat Penguasaan Siswa Berdasarkan Nilai Mean dan Standar Deviasi

\begin{tabular}{|c|c|c|c|c|c|c|c|c|}
\hline \multirow{3}{*}{$\begin{array}{l}\text { Nilai Mean dan } \\
\text { Standar Deviasi }\end{array}$} & \multicolumn{6}{|c|}{ Gaya Belajar } & \multirow{3}{*}{ Total } & \multirow{3}{*}{$\begin{array}{l}\text { Tingkat } \\
\text { Penguasaan }\end{array}$} \\
\hline & \multicolumn{2}{|c|}{ Visual } & \multicolumn{2}{|c|}{ Auditori } & \multicolumn{2}{|c|}{ Kinestetik } & & \\
\hline & $\sum$ Siswa & $\%$ & $\sum$ Siswa & $\%$ & $\sum$ Siswa & $\%$ & & \\
\hline$X \geq 60,6$ & 4 & 8,2 & 3 & 6,1 & 0 & 0 & $14.3 \%$ & Tinggi \\
\hline $27,4 \leq X \leq 60,6$ & 14 & 28,6 & 13 & 26,5 & 7 & 14,3 & $69,4 \%$ & Sedang \\
\hline $\mathrm{X} \leq 27,4$ & 3 & 6,1 & 0 & 0 & 5 & 10,2 & $16,3 \%$ & Rendah \\
\hline Total & 21 & 42,9 & 16 & 32,6 & 12 & 24,5 & $100 \%$ & \\
\hline
\end{tabular}

Keterangan : $\mathrm{X}$ adalah hasil tes siswa

\section{PENUTUP}

\section{Simpulan}

Berdasarkan hasil penelitian, analisis data penelitian dan pembahasan maka dapat disimpulkan bahwa tingkat penguasaan materi berdasarkan nilai KKM, menunjukkan bahwa tingkat penguasaan siswa visual pada materi soal cerita sistem persamaan linear tiga variabel ada empat siswa $(8,2 \%)$ yang menguasai dan ada 17 siswa $(34,7 \%)$ yang tidak menguasai. Tingkat penguasaan materi siswa auditori ada tiga siswa $(6,1 \%)$ yang menguasai dan ada 13 siswa $(26,5 \%)$ yang tidak menguasai. Tingkat penguasaan materi siswa kinestetik tidak ada siswa (0\%) yang menguasai dan ada 12 siswa (24.5\%) yang tidak menguasai.

Selain itu, tingkat penguasaan materi berdasarkan nilai mean dan standart deviasi, menunjukkan bahwa tingkat penguasaan siswa visual pada materi soal cerita sistem persamaan linear tiga variabel tergolong klasifikasi tinggi ada empat siswa $(8,2 \%)$, tergolong klasifikasi sedang ada 14 siswa $(28,6 \%)$, dan tergolong klasifikasi rendah ada tiga siswa $(6,1 \%)$. Tingkat penguasaan materi siswa auditori yang tergolong klasifikasi tinggi ada tiga siswa $(6,1 \%)$, tergolong klasifikasi sedang ada 13 siswa (26,5\%), dan tidak ada siswa $(0 \%)$ yang tergolong klasifikasi rendah. Tingkat penguasaan materi siswa kinestetik tergolong klasifikasi tinggi tidak ada (0\%), tergolong klasifikasi sedang ada tujuh siswa (14,3\%), dan yang tergolong klasifikasi rendah ada lima siswa $(10,2 \%)$.
Saran

Berdasarkan kesimpulan diatas maka peneliti menyarankan perlu dilakukan penelitian lanjutan yang dapat meningkatkan hasil belajar siswa terutama yang berkaitan dengan materi matematika yang abstrak, bentuknya soal cerita yang berkaitan dengan kehidupan sehari-hari. Penelitian lanjutan yang paling cocok adalah penelitian tindakan kelas, yang tentunya berkaitan dengan model pembelajaran yang digunakan guru yang dapat meningkatkan hasil belajar siswa khususnya siswa kelas X SMA Islam Parlaungan.

\section{DAFTAR PUSTAKA}

Arylien L.B, dkk. 2014. Pengaruh Gaya Belajar Visual, Auditori, dan Kinestetik Terhadap Prestasi Belajar Siswa. Jurnal Kependidikan, penelitian inovasi pembelajaran, Volume 44, Nomor 2. November 2014, Hal. 168-174, p-ISSN: 2580-5525, e-ISSN: 25805533, DOI: https://doi.org/10.21831/jk.v44i2.5307

Evie Noviyana, Chandra, 2016. Korelasi Penguasaan Materi Dasar dan Kemampuan Komunikasi terhadap Prestasi Belajar Matematika. Publikasi Ilmiah, Universitas Muhammadiyah Surakarta. http://eprints.ums.ac.id/44038/17/ARTIKEL\%20PUB LIKASI.pdf

Emzir. 2014. Metodologi Penelitian Kualitatif: Analisis Data. Jakarta: Rajawali Pers. 
Hartati Leny. 2013. Pengaruh Gaya Belajar Dan Sikap Siswa Pada Pelajaran Matematika Terhadap Hasil Belajar Matematika. Depok: Universitas Indraprasta PGRI. Jurnal Formatif Volume 3(3): 224-235 ISSN: 2088-351X,

https://journal.lppmunindra.ac.id/index.php/Formatif/ article/download/128/123

Hasratuddin. 2014. Pembelajaran Matematika Sekarang dan yang akan datang Berbasis Karakter. Jurnal Didaktik Matematika,Vol. 1 No. 2 September 2014,Hal. 30-42 p-ISSN: 2355-4185 e-ISSN: $2548-$ 8546 ,

http://www.jurnal.unsyiah.ac.id/DM/article/view/207 5

Julita. 2018. Peningkatan Kemampuan Pemecahan dan Hasil Belajar Matematika melalui Problem Based Learning. Jurnal Pendidikan Matematika "Mosharafa" Volume 7, Nomor 1, Januari 2018, hal. 143-154, pISSN: 2086-4280 e-ISSN: 2527-8827.

DOI: https://doi.org/10.31980/mosharafa.v7i1.350,

Web:

https://journal.institutpendidikan.ac.id/index.php/mos harafa/article/view/mv7n1_15

Moleong, L. 2015. Metodologi Penelitian Kualitatif. Bandung: Remaja Rosda Karya

Nyoto, Budi Usodo, Riyadi. 2015. Eksperimentasi Model Pembelajaran Kooperatif Tipe Think Pair Share (Tps) Dengan Pendekatan Realistic Mathematics Education (Rme) Ditinjau Dari Gaya Belajar Siswa Kelas Viii Smp/Mts Di Kabupaten Sragen. Surakarta : Universitas Sebelas Maret Surakarta. Jurnal Elektronik Pembelajaran Matematika ISSN: 2339-1685 Vol.3, No.5, hal 553-563 Juli 2015 http://jurnal.fkip.uns.ac.id

Rahmawati, Novika dan Maryono. 2018. Pemecahan Masalah Matematika Bentuk Soal Cerita Berdasarkan Model Polya pada Siswa Kelas VIII MTs Materi Pokok SPLDV. Jurnal Tadris Matematika 1(1). Juni 2018, Hal. 23-34. ISSN (Print): 2621-3990. ISSN (Online): 2621-4008. http://ejournal.iain-tulungagung.ac.id DOI: $10.21274 /$ jtm.2018.1.1.23-34

Siti Imroatun dkk. 2016. Strategi Pemecahan Masalah Matematika Siswa Kelas VII SMP Kristen 2 Salatiga ditinjau dari Langkah Polya. Universitas Kristen Satya Wacana.

http://repository.uksw.edu/bitstream/123456789/5624 /1/T1_202010062_Judul.pdf

Sudijono, A. 2012. Pengantar Evaluasi Pendidikan. Jakarta: PT Raja Grafindo Persada.

Sukardi. 2012. Metode Penelitian Pendidikan. Jakarta: Rineka Cipta

Sutrisno,.2013. Eksperimentasi Model Pembelajaran Kooperatif Tipe Stad Dan Tps Dengan Pendekatan Savi Terhadap Prestasi Dan Motivasi Belajar Ditinjau
Dari Gaya Belajar Siswa, Solo: Universitas Negeri Surakarta

Syukur, Muhamad dan Misu, La. 2016. Hubungan antara Gaya Belajar dengan Hasil Belajar Matematika Siswa Kelas XI SMAN 4 Kendari. Jurnal Penelitian Pendidikan Matematika Volume 4 No. 2, Mei 2016, Hal.153-166,Universitas Halu Oleo, www.jppm.holes 